\title{
Aktivitas Promoter â-aktin Ikan Medaka Jepang (Oryzias latipes) pada Ikan Mas (Cyprinus carpio)
}

\author{
Alimuddin ${ }^{1 *}$, Lola Irma Purwanti ${ }^{2)}$, MH. Fariduddin Ath-thar ${ }^{2)}$, Chairul Muluk1), \\ Odang Carman'1), dan Komar Sumantadinata ${ }^{1)}$ \\ 1)Departemen Budidaya Perairan, Fakultas Perikanan dan Ilmu Kelautan, IPB \\ ${ }^{2)}$ Alumni Departemen Budidaya Perairan, Fakultas Perikanan dan IImu Kelautan IPB \\ Kampus Darmaga, Bogor, 16680
}

Diterima 08-06-2008

Disetujui 25-11-2008

\begin{abstract}
This study was conducted to examine activity of medaka (Oryzias latipes) â-actin promoter (mBP) in common carp (Cyprinus carpio) as the first step towards development of common carp transgenic in country. Gene construct pmBP-hrGFP that consists of mBA promoter and humanized Renilla reniformis green fluorescent protein gene (hrGFP) was injected into cytoplasm of one cell stage of common carp by using microinjector. PmBP-hrGFP concentration used for microinjection was $50 \mu \mathrm{g} / \mathrm{mL}$ aquabides. Parameters observed were survival rate of embryo (SRe), hatching rate (HR) and expression of hrGFP gene. SRe was calculated before eggs hacthed, while hatching rate (HR) was after all of eggs hatched. The activity of mBA promoter was analyzed by observation of hrGFP gene transient expression using a fluorescence microscope. The results of experiment showed that $\mathrm{SRe}(87,5 \%)$ and HR (79.2\%) of control was respectevily higher than that of injected treatment $(75.0 \% \& 61.7 \%)$. Expression of hrGFP was observed firstly at blastula (12 hours after fertilization) to 1-day-old larval stages (24 hours after hatching) with higher gene expression at blastula to late gastrula stages. Percentage of micronjected larvae expressing hrGFP at 6 hours after hatching reached $71.6 \pm 6.7 \%$. Conclusion was that mBA promoter could drove hrGFP expression in common carp, hence it can be used to produce common carp transgenic by changing hrGFP with genes correlated with important traits in aquaculture.
\end{abstract}

Keywords: â-actin promoter, common carp, hrGFP, medaka, transgenic

\section{PENDAHULUAN}

Transgenesis merupakan teknik rekayasa genetik dengan cara mengintroduksi gen pengode karakter unik yang dapat memberikan nilai tambah bagi organisme target. Sebagai contoh, transfer gen pengode hormon pertumbuhan (growth hormone, GH) untuk meningkatkan laju pertumbuhan ikan hingga beberapa kali lipat (Devlin et al, 1994), dan gen cecropin (Dunham et al, 2002) atau lisozim (Yazawa et al, 2005) untuk meningkatkan resistensi ikan terhadap bakteri patogen. Transfer gen pengode enzim-enzim yang bekerja dalam biosintesa asam lemak rantai panjang tidak jenuh untuk meningkatkan kemampuan ikan dalam mensintesa asam lemak omega-3; asam ekosapentanat dan dokosaheksanat (Alimuddin et al, 2005; Alimuddin et al, 2007; Alimuddin et al, 2008). Selanjutnya, selain dapat meningkatkan kecepatan tumbuh ikan, transfer gen GH juga dapat menurunkan ekskresi ammonia,

\footnotetext{
*Telp: 0251-8622940, Fax. 0251-8622941
}

Email: alimuddin_alsani@yahoo.com sehingga kegiatan budidaya dengan ikan seperti ini juga menjadi lebih ramah lingkungan (Kobayashi et al, 2007).

Ekspresi gen asing atau transgen yang diintroduksi adalah dikontrol oleh suatu urutan DNA yang disebut promoter. Jenis promoter yang digunakan akan menentukan letak, waktu dan tingkat ekspresi transgen. Dalam hubungannya dengan tempat aktivitasnya, promoter dapat dibedakan menjadi promoter yang aktif di mana-mana (ubiquitous), dan promoter yang aktif pada jaringan tertentu seperti hanya aktif di hati, otak atau di gonad saja. Contoh promoter ubiquitous adalah promoter â-aktin, sementara promoter spesifik misalnya adalah promoter vasa yang aktif pada sel germinal (Yoshizaki et al, 2000). Jenis promoter lainnya adalah yang bersifat dapat diinduksi (inducible), yaitu promoter yang memerlukan faktor pemicu. Contoh promoter ini adalah promoter tumor necrosis factor yang memerlukan lipopolisakarida untuk meningkatkan aktivitasnya (Yazawa et al, 2005) dan promoter metallotionin yang aktivitasnya bergantung pada keberadaan logam berat (lyengar et al, 1996). 
Pada awal perkembangan transgenesis pada ikan, peneliti umumnya menggunakan promoter yang diperoleh dari vertebrata lain atau dari virus. Namun, penggunaan promoter tersebut menghasilkan ekspresi transgen yang rendah atau bahkan tidak menghasilkan ekspresi (Chourrout et al,1990; Penman et al, 1991). Hal ini diduga disebabkan oleh elemen cis-acting pada promoter dari vertebrata lain dan virus tidak dapat dikenali dengan baik oleh protein trans-acting ikan (Alimuddin 2003). Untuk mengatasi masalah tersebut, akhir-akhir ini dikembangkan konstruksi gen dengan menggunakan promoter yang berasal dari ikan. Selanjutnya, bila ikan transgenik dipasarkan, diduga bahwa penerimaan konsumen akan lebih baik pada ikan transgenik yang dibuat menggunakan konstruksi gen dengan promoter dan gen dari ikan, khususnya yang berasal dari spesies yang sama dibandingkan dengan yang berasal dari mamalia atau virus (Maclean \& Laight 2000).

Salah satu jenis promoter yang memiliki aktivitas tinggi pada beberapa jenis ikan adalah promoter â-aktin dari ikan medaka Jepang (Oryzias latipes). Promoter â-aktin ikan medaka menunjukkan aktivitas yang tinggi pada ikan medaka (Takagi et al, 1994; Hamada et al, 1998), ikan rainbow trout (Yoshizaki 2001; Boonanuntanasarn et al, 2002), ikan zebra (Alimuddin et al, 2005), ikan nila (Kobayashi et al, 2007) dan ikan lele (Ath-thar 2007). Namun aktivitas promoter ini belum pernah diujicobakan pada ikan mas (Cyprinus carpio). Ikan mas merupakan salah satu jenis ikan air tawar yang populer di Indonesia. Perbaikan kualitas genetik ikan mas menggunakan teknologi transgenesis di masa datang diduga akan meningkatkan produktivitas budidaya dan pendapatan petani. Sebagai tahap awal, pada penelitian ini, aktivitas promoter â-aktin ikan medaka diujicobakan pada ikan mas dengan harapan promoter tersebut dapat memberikan aktivitas yang tinggi sehingga dapat digunakan dalam pembuatan ikan mas transgenik untuk tujuan budidaya.

Untuk melihat aktivitas promoter, diperlukan adanya gen penanda yang disambungkan dengan promoter. Promoter dikatakan aktif apabila gen penanda dapat terekspresi. Gen penanda yang biasa digunakan dalam pengujian aktivitas promoter, yaitu lacZ, luciferase (luc), green fluorescent protein (GFP), dan chloramphenicol acetyl transferase (lyengar et al, 1996). Pada pengujian promoter â-aktin ikan medaka pada ikan mas digunakan gen penanda hrGFP (humanized Renilla reniformis green fluorescent protein) yang berasal dari Anthozoa jenis Renilla reniformis. Gen GFP mengkodekan protein berwarna hijau berpendar yang ekspresinya dapat diamati dengan mikroskop fluoresen (Felts et al, 2001). Kelebihan lainnya dari gen ini adalah memiliki tingkat sitotoksisitas yang rendah, tidak memerlukan substrat tambahan dan kofaktor untuk berpendar serta ekspresi transgen dapat tervisualisasi pada sel dengan menggunakan sinar UV sehingga memudahkan untuk memonitor ekspresinya. Apabila promoter â-aktin ikan medaka mampu mengendalikan ekspresi gen hrGFP pada ikan mas, maka diduga gen lain yang mengkodekan karakter penting dalam budidaya ikan dapat diintroduksikan sebagai pengganti gen hrGFP dalam proses transgenesis ikan mas.

Pengujian aktivitas promoter umumnya dilakukan dengan cara menginjeksikan konstruksi gen ke embrio dan kemudian mengamati ekspresi sementara (transient) dari gen penanda yang digunakan (Maclean et a, 2002; Takagi et al, 1994; Tsai et al, 1995; Maclean et al, 1996; Muller et al, 1997; Hamada et al, 1998; Alimuddin 2003; Kato et al, 2007) atau membuat ikan transgenik (Higashijima et al, 1997). Metode lain yang juga bisa digunakan adalah menginjeksi langsung konstruksi gen ke otot daging (Hansen et al, 1991; Rahman \& Maclean 1992) atau transfeksi ke sel kultur (Hwang et al, 2003; Kato et al, 2007). Metode injeksi langsung ke otot daging biasanya memerlukan tahap lanjutan seperti RT-PCR untuk melihat tingkat transkripsi RNA. Pengamatan ekspresi gen GFP pada daging ikan tempat injeksi relatif sulit dilakukan karena umumnya terhalang oleh pigmen kulit. Kelemahan metode transfeksi adalah berkaitan dengan tipe sel kultur yang digunakan, umumnya hanya satu jenis sel. Hal ini akan membatasi pengujian aktivitas hanya untuk promoter yang sesuai dengan sel tersebut, atau promoter yang aktif di mana-mana. Pada penelitian ini konstruksi gen diinjeksikan ke embrio ikan mas fase satu sel menggunakan mikroinjektor. Tujuan penelitian ini adalah untuk mengetahui aktivitas promoter â-aktin ikan medaka pada ikan mas, dengan cara mengamati ekspresi sementara dari gen hrGFP sebagai penanda.

\section{BAHAN DAN METODE}

Pengadaan Embrio ikan mas. Embrio ikan mas fase satu sel diperoleh dengan cara pemijahan buatan. 
Induk ikan mas betina yang matang gonad disuntik ovaprim dengan dosis $0,5 \mathrm{~mL} / \mathrm{kg}$ induk. Setelah induk memijah yang ditandai dengan adanya telur di kakaban, kedua induk ditangkap, kemudian telur dan sperma dikeluarkan dengan cara pengurutan (stripping). Telur dicampur dengan sperma dalam satu wadah berupa mangkuk, ditambahkan larutan pembuahan (3 g Urea ditambah $4 \mathrm{~g} \mathrm{NaCl}$ dilarutkan dengan $1 \mathrm{~L}$ air steril) (Woynarovich \& Horvath 1980), dan diaduk menggunakan bulu ayam. Setelah itu telur dibilas kembali dengan larutan pembuahan sebanyak 2-3 kali. Untuk menghilangkan daya rekatnya, telur yang telah dibilas dengan larutan pembuahan dicelup ke dalam larutan Tannin (0,5 g Tannin dilarutkan dengan $1 \mathrm{LSDW}$ ) (Woynarovich \& Horvath 1980) yang masih baru selama 3-5 detik, kemudian segera dibilas dengan air bersih sebanyak 2 kali. Embrio-embrio tersebut selanjutnya diinkubasi dalam akuarium dengan suhu air sekitar $24^{\circ} \mathrm{C}$ di Laboratorum Pengembangbiakan dan Genetika Ikan, BDP, FPIK, IPB.

Pembuatan Cekungan Gel Agarosa. Cekungan dari gel agarosa berfungsi sebagai penahan embrio supaya tidak bergerak pada saat diinjeksi dengan jarum. Metode pembuatan cekungan gel agarosa mengikuti metode Alimuddin (2003). Sebanyak $30 \mathrm{~mL}$ agarosa $2 \%$ (dalam akuades) hangat dituangkan ke dalam cawan petri yang sebelumnya telah diletakkan cetakan marmer di dalamnya. Setelah agarosa menjadi padat, cetakan marmer diambil sehingga terbentuk cekungan (Gambar 1a) sebagai tempat meletakkan embrio ikan. Setelah digunakan, cekungan gel agarosa dibilas dengan etanol $70 \%$ dan akuades, kemudian ditutup dengan plastik sebelum disimpan di dalam lemari es. Cekungan gel agarosa ini dapat digunakan beberapa kali.
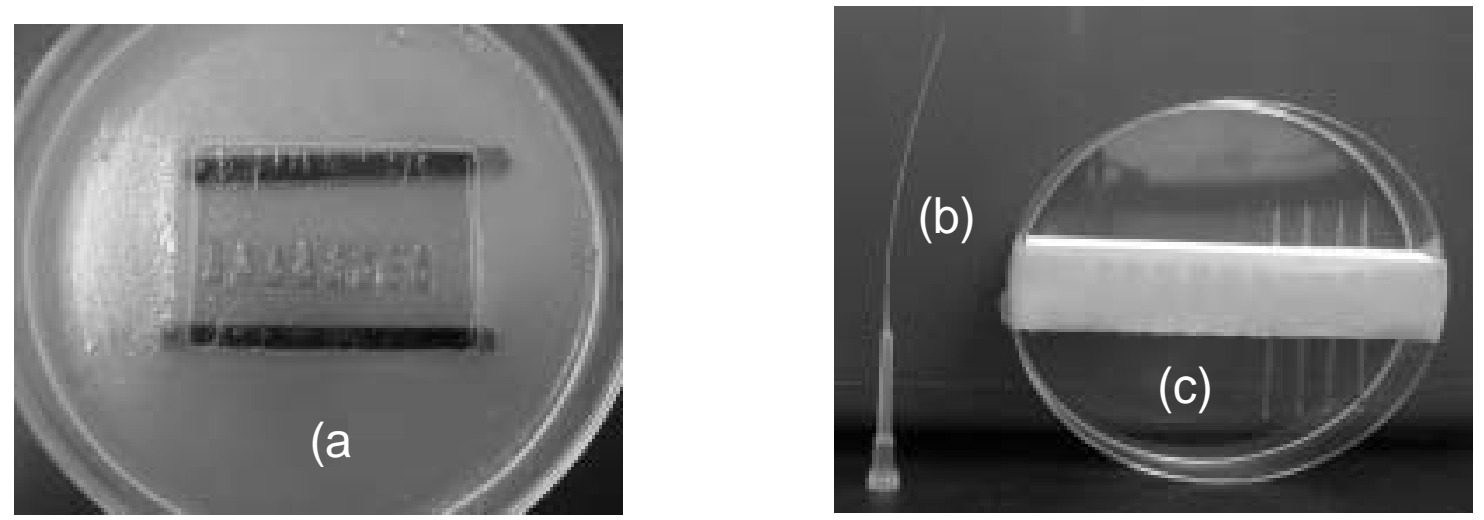

Gambar 1. Cekungan gel agarosa (a), tip mikropipet (b) dan jarum mikroinjeksi (c).

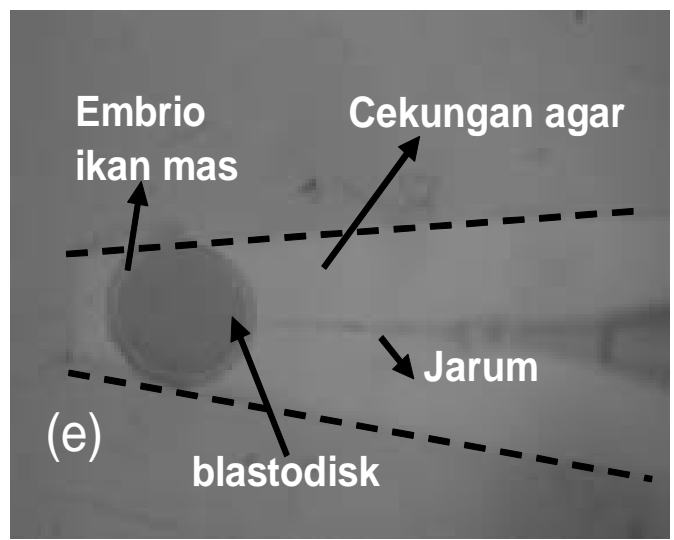

Gambar 2. Penahan jarum (a), mikroinjektor (b), mikroskop (c), mikromanipulator (d) dan gel agarosa sebagai penyangga embrio saat injeksi (e). 
Pelaksanaan Mikroinjeksi. Konsentrasi plasmid DNA, pmBP-hrGFP (Sawayama 2006), yang digunakan untuk mikroinjeksi ikan mas yaitu $50 \mu \mathrm{g} / \mathrm{mL}$ akuabides. Sebanyak $10 \mu \mathrm{L}$ larutan DNA diambil menggunakan mikropipet dengan tip panjang dibagian ujungnya (Gambar 1b) dan kemudian dimasukkan ke dalam jarum mikroinjeksi (Gambar 1c). Ukuran bukaan mulut jarum mikroinjeksi adalah sekitar 5-7 $\mu \mathrm{m}$. Cara pembuatan jarum mikroinjeksi seperti dijelaskan dalam Alimuddin (2003). Jarum mikroinjeksi yang berisi larutan DNA disambungkan ke penahan jarum (Gambar 2a) pada sistem mikroinjektor (Gambar 2b).

Embrio ikan mas fase 1 sel diletakkan dan diatur secara hati-hati ke dalam cekungan gel agarosa menggunakan pipet. Posisi telur diatur sedemikian rupa sehingga blastodisk mengarah ke jarum mikroinjeksi untuk memudahkan proses injeksi (Gambar 2e). Mikroinjeksi dilakukan di bawah mikroskop (Gambar 2c). Jarum mikroinjeksi digerakkan menggunakan mikromanipulator (Gambar 2d). Perlakuan injeksi dilakukan sebanyak 3 kali ulangan dari induk ikan mas yang berbeda. Jumlah telur yang diinjeksi sebanyak 40 butir tiap ulangan.

Telur-telur yang telah diinjeksi dipindahkan ke dalam akuarium inkubasi. Suhu air akuarium inkubasi adalah $24 \pm 1^{\circ} \mathrm{C}$. Setiap hari, telur yang tidak dibuahi atau mengalami deformasi dibuang.

Pengamatan Ekspresi Gen hrGFP. Pengamatan ekspresi hrGFP dilakukan dengan menggunakan mikroskop fluoresen (Olympus, BH2) yang dilengkapi dengan reflected light fluorescence attachment pada perbesaran 40x. Dua belas jam setelah injeksi, pada saat ekspresi transgen telah terlihat dengan jelas, pengamatan dilakukan setiap 6 jam untuk mengamati perkembangan ekspresi hrGFP hingga ekspresinya tidak kelihatan. Embrio dan larva difoto menggunakan kamera digital kemudian ditransfer ke komputer.

Analisis Data. Parameter yang diamati meliputi derajat kelangsungan hidup embrio (DKH-e), derajat penetasan (DP) dan persentase larva mengekspresikan transgen (PLMT). DKH-e adalah persentase jumlah embrio yang hidup dibandingkan jumlah embrio awal. Perhitungan DKH-e dilakukan sekitar 36 jam setelah pembuahan, di mana telur belum menetas. DP adalah persentase jumlah telur yang menetas dibandingkan jumlah awal embrio. Perhitungan dilakukan ketika telur telah menetas secara keseluruhan. PLMT didapatkan dari perbandingan jumlah larva yang mengekspresikan gen hrGFP dibandingkan dengan jumlah total telur injeksi yang menetas. Perhitungan persentase tersebut dilakukan 6 jam setelah telur menetas menjadi larva. Data hasil pengamatan dan penghitungan dari ketiga ulangan dirata-ratakan dan kemudian dianalisis secara deskriptif selanjutnya disajikan dalam bentuk tabel dan gambar.

\section{HASIL DAN PEMBAHASAN}

Hasil. Nilai DKH-e, DP dan PLMT diperlihatkan pada Tabel 1. Baik DKH-e $(87,5 \pm 2,5 \%$ vs $75,0 \pm 2,5 \%)$ maupun DP $(79,2 \pm 2,9 \%$ vs. $61,7 \pm 3,8 \%)$ pada kontrol lebih tinggi dibandingkan dengan perlakuan mikroinjeksi. Sementara itu PLMT hanya ditemukan pada perlakuan mikroinjeksi (Tabel 1).

Penampakan embrio dan larva yang mengekspresikan transgen dapat dibedakan dengan yang tidak mengekspresikannya dengan menggunakan mikroskop fluoresen. Ekspresi transgen mulai terlihat pada saat fase blastula ( 12 jam setelah pembuahan) di bagian blastoderm (Gambar 3a) hingga larva berumur 1 hari (24 jam setelah telur menetas). Ekspresi transgen terkuat teramati di bagian blastoderm pada fase blastula hingga akhir gastrula (18 jam setelah pembuahan). Setelah menetas, beberapa larva memiliki ekspresi hrGFP beberapa organ seperti otot daging, pembuluh darah, epidermis, dan kepala (gambar tidak diperlihatkan). Contoh larva mengekspresikan gen hrGFP yang didokumentasikan saat sekitar 6 jam setelah menetas ditunjukkan pada Gambar 4a. Namun ekspresi hrGFP tersebut mulai tidak kelihatan setelah larva berumur 1 hari (24 jam setelah menetas).

Pembahasan. Pada perlakuan mikroinjeksi, nilai DP lebih rendah dibandingkan dengan kontrol. Rendahnya nilai DP disebabkan karena terjadinya

Tabel 1. Derajat kelangsungan hidup embrio (DKH-e) derajat penetasan (DP), dan persentase larva mengekspresikan transgen (PLMT) pada perlakuan kontrol dan mikroinjeksi embrio ikan mas

\begin{tabular}{lcccc}
\hline Perlakuan & $\begin{array}{c}\text { Jumlah } \\
\text { embrio awal } \\
\text { (butir) }\end{array}$ & DKH-e (\%) & DP (\%) & PLMT (\%) \\
\hline Kontrol & $40(n=3)$ & $87,5 \pm 2,5$ & $79,2 \pm 2,9$ & $0,0 \pm 0,0$ \\
Mikroinjeksi & $40(n=3)$ & $75,0 \pm 2,5$ & $61,7 \pm 3,8$ & $71,6 \pm 6,7$ \\
\hline
\end{tabular}


kematian embrio yang cukup tinggi pada telur yang diinjeksi sebelum terjadinya proses penetasan. Hal ini dapat terlihat dari nilai DKH-e pada perlakuan injeksi yang lebih kecil dari nilai DKH-e pada kontrol saat 36 jam setelah injeksi. Rendahnya nilai DKH-e ini diduga disebabkan adanya kerusakan sel akibat injeksi. Selain itu, faktor lain yang mungkin menyebabkan banyaknya embrio yang mati pada perlakuan injeksi adalah volume cairan DNA yang diinjeksikan terlalu banyak. Nilai DP dan $\mathrm{DKH}-\mathrm{e}$ pada perlakuan injeksi diduga dapat ditingkatkan hingga mendekati atau bahkan sama dengan kontrol melalui latihan injeksi terus menerus atau menurunkan dosis DNA yang diinjeksikan. Pada penelitian ini tidak dilakukan optimasi dosis DNA yang diinjeksikan untuk meningkatkan kelangsungan hidup embrio dan derajat penetasan.

Kemampuan promoter dalam mengendalikan ekspresi gen asing yang diintroduksi merupakan salah satu faktor penentu keberhasilan transgenesis. Pada penelitian ini dilakukan pengujian aktivitas promoter âaktin dari ikan medaka (mBP) pada ikan mas dalam rangka perbaikan kualitas induk dan benih ikan mas melalui rekayasa gen. Aktivitas promoter bisa diketahui dengan cara mengamati ekspresi gen penanda yang disambungkan dengannya. Pada penelitian ini digunakan gen penanda hrGFP, gen pengode protein berpendar hijau, yang ekspresinya dapat dilihat secara visual menggunakan mikrospkop fluoresen. Ekspresi gen hrGFP yang diamati di embrio hasil mikroinjeksi adalah bersifat sementara (transient expression), dalam arti bahwa pada awalnya ekspresi gen rendah, meningkat dan kemudian pada akhirnya menurun hingga tidak dapat terlihat. Hasil pengamatan menunjukkan bahwa ekspresi gen hrGFP mulai terlihat di embrio ikan mas pada fase blastula (12 jam setelah pembuahan) di bagian blastoderm. Ekspresi transgen terkuat terlihat di bagian blastoderm pada fase blastula hingga gastrula akhir (18 jam setelah pembuahan). Hal ini menunjukkan bahwa promoter mBP dapat aktif pada ikan mas.

Dengan menggunakan promoter yang sama, gen wild-type GFP (wtGFP) pada ikan medaka mulai terekspresi pada fase mid-blastula dan ekspresi terkuat teramati hingga fase gastrula akhir (Hamada et al, 1998). Begitu pula ditemukan pada penelitian Ath-thar (2007) bahwa ekspresi sementara gen hrGFP pada telur lele mulai muncul pada fase gastrula awal atau fase permulaan adanya epiboly. Tingkat ekspresi gen asing yang tinggi setelah fase mid-blastula hingga fase gastrula kemungkinan sebagai hasil dari akumulasi DNA yang diinjeksikan yang berlanjut pada peningkatan replikasi selama fase pembelahan (cleavage) dan akumulasi dari RNA polymerase II yang menyebabkan dimulainya transkripsi pada mid-blastula transition (lyengar et al, 1996). Menurut Etkin et al, (1984) cit Winkler et al, (1991), replikasi dari DNA asing ditemukan hanya sampai fase gastrula sedangkan pada embrio yang sudah melewati fase tersebut, DNA asing yang bertahan hanya dalam jumlah yang terbatas akibat adanya degradasi oleh enzim restriksi sehingga ekspresi transgen melemah. Hal lain yang diduga menyebabkan tingginya ekspresi transgen adalah terekspresinya plasmid-plasmid DNA, tetapi seiring dengan fase perkembangan larva, plasmid-plasmid DNA tersebut ikut terdegradasi.

Setelah menetas, ekspresi transgen masih tetap terlihat pada larva, sekitar $71,61 \% \pm 6,76 \%$ larva mengekspresikan transgen, tetapi ekspresi tersebut tidak spesifik pada suatu organ. Hal ini berkenaan dengan sifat promoter â-aktin yang dapat aktif pada semua jaringan/ sel otot. Akan tetapi pada penelitian ini, ekpresi gen hrGFP tidak ditemukan pada semua sel organ melainkan hanya terdapat pada beberapa organ larva seperti pembuluh darah, kuning telur, epidermis kepala, badan dan ekor. Hal ini dijelaskan oleh lyengar et al, (1996), bahwa pada awal perkembangan embrio, gen yang ditransfer akan direplikasi tanpa mengalami integrasi ke dalam genom respien. Lebih lanjut dijelaskan bahwa setelah mengalami beberapa pembelahan sel, sebagian gen asing tersebut terintegrasi secara acak ke dalam genom respien di salah satu blastomer sehingga akan terdapat dua macam sel, yaitu sel yang membawa transgen dan sel yang tidak membawa transgen. Hal ini mengakibatkan tidak semua sel membawa transgen atau dikenal dengan istilah kejadian mosaik (mosaic). Menurut Chou et al, (2001) ketika fragmen DNA yang terdiri dari suatu gen target atau gen penanda homolog maupun heterolog ditransfer, maka akan sangat umum untuk menemukan kejadian mosaik. Liang et al, (2000) cit Chou et al, (2001) mengemukakan bahwa pengintegrasian transgen secara mosaik dalam ikan transgenik keturunan nol (F0 "founders") sering terdeteksi. Untuk mengurangi tingginya kejadian mosaik 
ini, mikroinjeksi sebaiknya dilakukan pada fase 1 se untuk mendistribusikan gen ke setiap sel yang membelah. Sebab apabila mikroinjeksi dilakukan hanya ke dalam salah satu blastomer setelah pembelahan sel, maka gen hanya bisa didistribusikan dari sel yang disuntik tadi. Apalagi mengingat pernyataan lyengar et al, (1996) bahwa integrasi biasanya terjadi setelah sel membelah beberapa kali. Hal ini dibuktikan dengan pernyataan (Ath-thar 2007) bahwa persentase dari jumlah telur yang mengekspresikan hrGFP lebih tinggi pada telur yang disuntik saat fase 1 sel daripada fase 2 sel.

Ekspresi transgen masih ditemukan pada larva ikan mas hingga 18 jam setelah penetasan. Namun ekspresi pada larva tersebut mulai tidak terlihat setelah larva berumur 1 hari (24 jam setelah menetas), sehingga ekpresi gen hrGFP yang ditemukan tergolong ekspresi sementara (transient expression). Hal ini diduga disebabkan berkurangnya jumlah copy gen akibat adanya degradasi dari plasmid-plasmid DNA, sehingga tidak memungkinkan ekspresi teramati. Hal lain dijelaskan oleh Alimuddin et al, (2003) bahwa selain terintegrasi ke dalam genom, ada sebagian dari gen asing berada dalam suatu posisi ekstrakromosomal. Lebih lanjut dijelaskan bahwa gen asing yang terintegrasi akan stabil di dalam genom, sementara dalam bentuk ekstrakromosomal akan terdegradasi oleh endogeneus nuclease. Dengan demikian, gen asing yang berada pada posisi ekstrakromosomal tersebut yang diduga mengakibatkan berkurangnya jumlah copy gen pada sel sehingga ekspresi dari gen hrGFP tidak kelihatan.

\section{KESIMPULAN}

Ekspresi sementara gen hrGFP dengan level tertinggi terlihat pada fase blastula hingga gastrula akhir, dan mulai tidak terlihat setelah larva berumur 1 hari $(24$ jam setelah menetas). Promoter â-aktin ikan medaka Jepang dapat aktif dan mampu mengendalikan ekspresi gen hrGFP pada embrio dan larva ikan mas. Promoter â-aktin ikan medaka Jepang dapat digunakan untuk pengembangan ikan mas transgenik dengan mengganti gen penanda hrGFP dengan gen target yang diinginkan.

\section{UCAPAN TERIMAKASIH}

Penulis mengucapkan terimakasih kepada Prof. dr. Goro Yoshizaki (Tokyo University of Marine Science and
Techology, Jepang) yang memberikan konstruksi gen yang digunakan dalam penelitian ini.

\section{DAFTAR PUSTAKA}

Alimuddin, Kiron, V., Satoh, S., Takeuchi, T. \& Yoshizaki, G. 2008. Cloning and expression of masu salmon elongaselike gene in zebrafish. Aquaculture 282:13-18.

Alimuddin, Yoshizaki, G., Carman, O. \& Sumantadinata, K. 2003. Aplikasi transfer gen dalam akuakultur. Jurnal Akuakultur Indonesia 2: 41-50.

Alimuddin, Yoshizaki, G., Kiron, V., Satoh, S. \& Takeuchi, T. 2005. Enhancement of EPA and DHA biosynthesis by overexpression of masu salmon "6-desaturase-like gene in zebrafish. Transgenic Research 14:159-165.

Alimuddin, Yoshizaki, G., Kiron, V., Satoh, S. \& Takeuchi, T. 2007. Over-expression of masu salmon "5-desaturase-like gene elevated EPA and DHA biosynthesis in zebrafish. Marine Biotechnolog 9: 92-100.

Alimuddin. 2003. Introduction and expression of foreign $\Delta 6$ desaturase-like gene in a teleostean fish. Thesis Graduate School of Fisheries Science. Japan: Tokyo University of Fisheries.

Ath-thar, M.F. 2007. Efektivitas promoter â-actin ikan medaka (Oryzias latipes) dengan penanda gen hrGFP (humanized Renilla reniformis Green Fluorescent Protein) pada ikan lele (Clarias sp.) keturunan F0. Skripsi Departemen Budidaya Perairan. Fakultas Perikanan dan IImu Kelautan. Bogor: Institut Pertanian Bogor.

Boonanuntanasarn, S., Yoshizaki, G., Takeuchi, Y., Morita, T. \& Takeuchi, T. 2002. Gene knock-down in rainbow trout embryo using antisense morpholino phosphorodiamidate oligonucleotides. Marine Biotechnology 4: 248-257.

Chou, C.Y., Horng, L.S. \& Tsai, H.J. 2001. Uniform GFPexpression in transgenic medaka Oryzias latipes at the F0 generation. Transgenic Research 10: 303-315

Chourrout, D.R., Guyomard, R. \& Houdebine, L.M. 1990. Techniques for the development of transgenic fish- a review. Di dalam: Church, R.B. (ed.). Transgenic Models in Medicine and Agriculture. Wiley-Liss, New York.

Devlin, R.H. 1997. Transgenic salmonids. Di dalam: Houdebine, L.M. (Ed.). Transgenic Animal: Generation and Use. Harewood Academic Publishers. Amsterdam: The Netherlands.

Devlin, R.H., Yesaki, T.Y., Donaldson, E.M., Du, S.J. \& Hew, C.L. 1994. Production of germline transgenic Pacific salmonids with dramatically increased growth performance. Canadian Journal of Fisheries Aquatic Sciences 52: 13761384

Dunham, R.E., Warr, G.W., Nicholas, A., Duncan, P.L., Argue, B., Middleton, D. \& Kucuktas, H. 2002. Enhanced bacterial disease resistance of transgenic channel catfish Ictalurus punctatus possessing cecropin genes. Marine Biotechnology 4: 338-344.

Felts, K., Rogers, B., Chen, K., Ji, H., Sorge, J. \& Vaillancourt, P. 2001. Recombinant Renilla reniformis GFP displays low toxicity. Stratagene 13: 85-87

Hamada, K., Tamaki, K., Sasado, T., Watai, Y., Kani, S., Wakamatsu, Y., Ozato, K., Kinoshita, M., Kohno, R., Takagi, S. \& Kimura, M. 1998. Usefulness of the medaka â-actin promoter investigated using a mutant GFP reporter gene in transgenic medaka Oryzias latipes. Molecular Marine Biology and Biotechnology 7: 173-180.

Hansen, E., Fernandes, K., Goldspink, G., Butterworth, P., Umeda, P.K. \& Chang, K-C. 1991. Strong expression of foreign genes following direct injection into fish muscle. FEBS Lett. 290: 73-76.

Higashijima, S., Okamoto, H., Ueno, N., Hotta, Y. \& Eguchi, G. 1997. High frequency generation of transgenic zebrafish which reliably express GFP in whole muscles or the whole body by using promoters of zebrafish origin. Dev. Biol. 192 : 289-299. 
Hwang, G-L., Rahman, M.A., Razak, S.A., Sohm, F., Farahmand, H., Smith, A., Brooks, C. \& Maclean, N. 2003. Isolation and characterisation of tilapia â-actin promoter and comparison of its activity with carp â-actin promoter. Biochimica et Biophysica Act 1625: 11-18

lyengar, A., Muller, F. \& Maclean, N. 1996. Regulation and expression of transgenes fish-a review. Transgenic Research 5: 147-166.

Kato, K., Takagi, M., Tamaru, Y., Akiyama, S-I., Konishi, T., Murata, O. \& Kumai, H. 2007. Construction of an expression vector containing a â-actin promoter region for gene transfer by microinjection in red sea bream Pagrus major. Fisheries Science 73: 440-445.

Kobayashi, S-I., Alimuddin, Morita, T., Miwa, M., Lu, J., Endo, M., Takeuchi, T. \& Yoshizaki, G. 2007. Transgenic Nile tilapia Oreochromis niloticus over-expressing growth hormone show reduced ammonia excretion. Aquaculture 270: 427-435.

Maclean, N. \& Laight, R.J. 2000. Transgenic fish - an evaluation of benefits and risks. Fish Fish 1: 146-172.

Maclean, N., Alam, M.S., lyengar, A. \& Popplewell, A. 1996. Transient expression of reporter genes in fish as a measure of promoter efficiency. Di dalam: Ennion, S.J. \& Goldspink, G. (Eds.). Gene Expression and Manipulation in Aquatic Organisms. Society for Experimental Biology Seminar Series, vol. 58. Cambridge: Cambridge Univ. Press.

Maclean, N., Hwang, G-L. \& Farahmand, T. 2002. Exploiting transgenic tilapia and the tilapia genome. Di dalam: Shimizu, N., Aoki, T., Hirono, I. \& Takashima, F. (Eds.). Aquatic Genomics. Tokyo: Springer-Verlag.

Muller, F., Williams, D.W., Kobolak, J., Gauvry, L., Goldspink, G., Orban, L. \& Maclean, N. 1997. Activator effect of coinjected enhancers on the muscle-specific expression of promoters in zebrafish embryos. Mol. Reprod. Dev. 47 404- 412.
Penman, D.J., lyengar, A., Beeching, A.J., Rahman, A., Sulaiman, Z. \& Maclean, N. 1991. Patterns of transgene inheritance in rainbow trout (Oncorhynchus mykiss). Mol. Reprod. Dev. 30: 201- 206.

Rahman, M.A. \& Maclean, N. 1992. Fish transgene expression by direct injection into fish muscle, Mol. Mar. Biol. Biotechnol 1: $286-289$.

Sawayama, A. 2006. Membuat vektor ekspresi untuk mendapatkan ekspresi gen yang tinggi dengan memodifikasi 3'UTR. Thesis Graduate School of Fisheries Science. Japan: Tokyo University of Marine Science and Technology.

Takagi, S., Sasado, G., Tamiya, G., Ozato, K., Wakamatsu, Y., Takeshita, A. \& Kimura, M. 1994. An efficient expression vector for transgenic medaka construction. Molecular Marine Biology and Biotechnology 3: 192-199.

Tsai, H-J., Wang, S-H., Inoue, K., Takagi, S., Kimura, M., Wakamatsu, Y. \& Ozato, K. 1995. Initiation of the transgenic LacZ gene expression in medaka (Oryzias latipes) embryos. Mol. Mar. Biol. Biotechnol 4: 1- 9.

Winkler, C., Vielkind, J.R. \& Schartl, M. 1991. Transient expression of foreign DNA during embryonic and larval development of the medaka fish Oryzias latipes. Molecular General Genetics 226: 129-140.

Woynarovich, E. \& Horvath, L. 1980. The Artificial Propagation of Warm-water Finfishes- A Manual for Extension. FAO Fish. Tech. Pap.

Yazawa, R., Hirono, I. \& Aoki, T. 2005. Characterization of promoter activities of four different Japanese flounder promoters in transgenic zebrafish. Marine Biotechnology 7: 625-633.

Yoshizaki, G. 2001. Gene transfer in salmonidae: applications to aquaculture. Suisanzoshoku 49:137-142.

Yoshizaki, G., Takeuchi, Y., Sakatani, S. \& Takeuchi, T. 2000. Germ cell-specific expression of green fluorescent protein in transgenic rainbow trout under the control of the rainbow trout vasa-like gene promoter. Int. J. Dev. Biol. 44: 323-326. 